\title{
THE ACCURACY OF FISH OTOLITH ANALYSIS AND SOME VALIDATION METHODS
}

\author{
Do Huu Hoang \\ Institute of Oceanography-VAST \\ Email: dohuuhoang2002@yahoo.com
}

Received: 29-3-2014

\begin{abstract}
Age structure and growth of fish are the extremely important data in fishery management. The data help policy makers have good strategies to manage and catch fish more effectively and sustainably. Although there are many studies on fish age determination based on otolith, the methods are still essential to be validated for each species, each method and studied area, because fish otolith formation is affected by many endogenous and exogenous factors. This paper shows the fish otolith function and its formation and introduces some validation methods, including: rearing fish, mark and release, radiometric assessment, assays of bomb radiocarbon, counting daily increments between annuli, length-frequency modes and validating the first growth increment.
\end{abstract}

Keywords: Otolith, age determination, growth, validation methods.

\section{INTRODUCTION}

Age determination is very important in fisheries researches. Age information combined with length of fish, fecundity, spawning season and fishery data, are used to build reliable stock assessments. With age data, fisheries managers can choose from reasonable models to ultimately determine the impact of a fishery, and these model predictions are the basis of catch and effort regulations.

There are many methods to estimate age of the fish and aquatic organisms such as length frequency analysis, mark-recapture, or hard part analyses [1-5]. Hard part analyses are more accurate and precise which are based on the hard parts of animals such as scales of fish, fish bone, opercula, spines or fin rays, or otoliths, the shells of bivalves and gastropods or the statoliths of squids.

Otolith of fish has been increasingly used in fisheries study because it is more accurate and precise than other hard part analyses and it is possible to use in various fisheries studies. Recognition of annual patterns requires the understanding of how the patterns relate to the annual growth cycle of fish.

Although, otolith analyses are more and more applied to fish researches such as: migration, spawning, life histories, stock identification and age determination, it is necessary to validate the age of fish based on the otolith increments/rings [3]. However, the formations of rings on the otolith may depend on many factors such as seasons, moon or tide cycle, environmental changes, feed availability, life stage or physiology of fish. Thus the rings on the otolith may represent for year, month or day or other conditional changes in the specific area where the fish live. Therefore, it is very essential to prove the accuracy and precision of a fish age determination method. Age determination techniques must also be validated for all age classes in the population 
and for each time and method that are applied to a new species or sometimes to different population or stock [6]. The reason is that the formation of otolith differs among fish species, development stages and is affected by various endogenous and exogenous factors [3]. A use of inaccurate ages has caused serious errors in fishery management and understanding of fish population [7].

Despite many studies on fish otolith and applications for temperate fish as well as tropical fish, there were few publications on otolith of fish in Vietnamese waters for example Do Huu et al. [8] described the otolith of Vietnamese seahorse (Hippocampus spinosissimus) including otolith microstructure, correlation between otolith size and seahorse length. Another study reviewed methods of fish age determination based on otolith analysis [9]. The author also discussed factors influencing otolith analysis including geography, species, life stages and the more difficulties in age determination of tropical fish species than the temperate species. In addition, morphological otolith of Cyprinidae was also described by Hung and Loi [10]. However, there was no publication in Viet Nam on the validation methods of fish otolith analysis. Therefore, this paper introduces some methods of validating age determination based on fish otolith. Some methods are cheap and easy to apply in present conditions of Vietnam, which open a prospect for fishery researches in the future.

\section{OTOLITH FUNCTION AND FORMATION}

Otoliths ("earstones") are small, white calcium structures found in the head of most teleost fishes, except sharks and rays [11]. They are located over sensory tissue in the ear and stimulate hair cells when they are moved or vibrated. This allows the fish to detect sound, gravity and acceleration [12]. The teleost fish has three pairs of otoliths [13]. The biggest pair (normally the sagitta) is usually used for age determination and other studies [14]. Lapillus is also used for ageing purpose on the daily level, but asteriscus is very small and fragile or shows irregular incremental patterns [15].

Otoliths are made up of a special calcium structure and matrix of protein called otolin. It is unique calcium carbonate tissue while bone, tooth, and scale are calcium phosphate. It is a metabolically inert [16]. The growth of fish otolith is an one-way process: new materials cover the surface of the old layer through time, but existing material cannot be removed and these characteristics make otolith more durable than bone [11].

The deposited materials on the otolith come from ambient water through metabolic process. Otolith formations are different among species and development stages. The factors affecting the formation of the otolith are not fully understood, however photoperiod, temperature, food availability, growth, reproductive activity have all been proposed [1]. One experiment on Atlantic croaker (Micropogonias undulatus) that was reared under different conditions in laboratory showed that otolith formation was affected by interaction between endogenous and exogenous processes, including water temperature, salinity, and ontogeny [17]. An experiment on the embryo, larvae and juveniles of the mummichog (Fundulus heteroclitus) showed that temperature significantly affected length of larvae and the otolith [18]. The deposit rate of materials seems more condensed in slow growing fish, resulting in heavier otolith in slower growing fish than faster ones, therefore; length and weight of otolith could be used to estimate growth of fish [19].

Scales, bones, fin rays and otoliths often form yearly rings (annuli) like those of a tree [11]. During the winter the fish grow very slowly, so the ring formation is condensed and creates the dark zones, called winter zones (translucent), and during the summer the fish grow faster, it forms summer zones (opaque) on the otolith. A year's growth of the otolith consists of both opaque and translucent zones. The majority of fish were forming opaque zones during the spring and summer months. The translucent zones are dominated by organic material while the opaque zones are dominated by carbonate [11].

The feeding frequency affected both the rate of formation and distance between annuli [20]. Lunar cycle probably has great impact on some fish species by the tidal cycle [2]. 
Campana [21] showed that juveniles of starry flounder (Platichthys stellatus) expressed 15 day checks (marks) in the otolith and it was related to the tidal cycle. He stated that it might be caused by salinity and temperature more than by other factors.

Alternate zones of thick band is known as the incremental zones, and thin band is known as discontinuous zones that are deposited daily and both of which form increment zones. The daily increments in temperate fish were firstly examined by Pannella [22]. He counted the average increment numbers between two annuli to 360 daily increments. Campana and Neilson [2] showed that the growth increments were formed as a result of an endogenous diurnal rhythm. An experiment on Hirundichthys affinis larvae showed that the periodicity of otolith increments was not affected by photoperiod [23]. In contrast, many results showed the light affected otolith formation, result on embryo and larvae of Fundulus heteroclitus showed that the light significantly affected the formation of the otolith [18].

The first daily increment can be formed at different date from hatch date. Fundulus heteroclitus has two daily increments before hatching. Other species such as Engraulis mordax has increment at sixth day after hatching and Ammodytes dubius has first increment at postlarvae (length $2.4 \mathrm{~cm}$ ) [18].

\section{THE ACCURACY AND PRECISION IN FISH AGE DETERMINATION}

In the past, many authors have considered precision (repeatability) as accuracy [7].

Accuracy is the closeness of a measured value to its true value and precision is the closeness of repeated measurements to the same value [4]. Age determination of fish has two sources of errors: firstly, not all the hard structures of the fish (otolith, scale, vertebrate, opercula, fin ray) are formed completely through time, this type of error causes under or overestimation; and second error of subjectivity is found for all age estimations. These biases are originating from preparation and interpretation of the period formation in the calcium structures and from a variation among age readers and laboratories [3]. Indeed the first error can be proved as Radtke and Dean had done [18]; the calcification on the core of the embryo showed at fourth day from fertilized date. And many studies also showed the first increment was not formed at hatching date [18].

\section{Accuracy and precision among hart part analysis of fish}

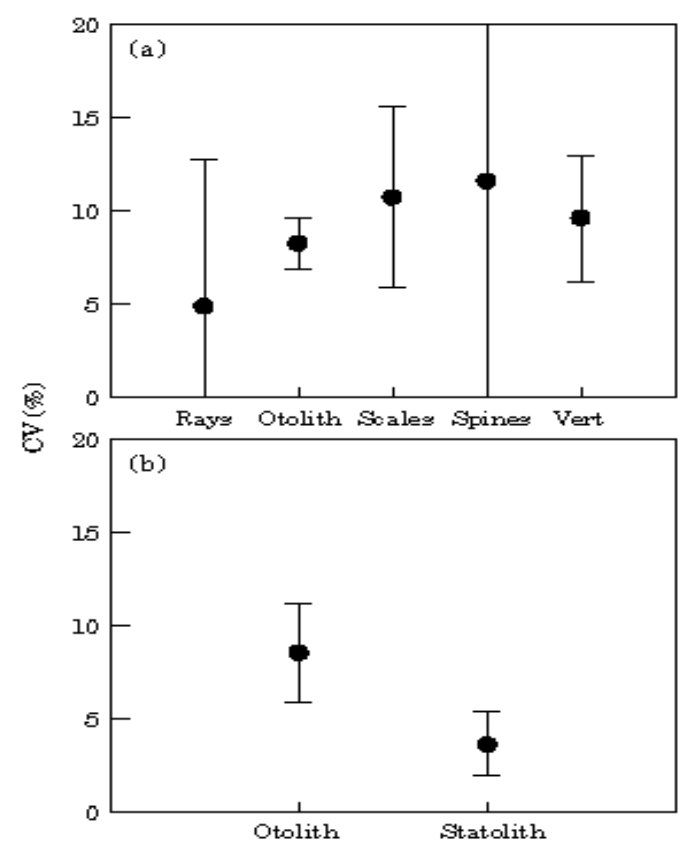

Fig. 1. Reported precision (calculated as CV) for the most frequently aged structures at both the annual (a) and daily (b) level. Error bars represent the mean of $95 \%$ confidence interval; Vert: vertebrate [3]

Age determination based on otolith size is a better method than length frequency analysis; because the otolith growth is tightly related to somatic growth. Nowadays, scientists use more advanced techniques for reading the annual and daily increments [3].

The scale method was less precise than otolith method, because of lower percent agreement than otolith method [24]. Age estimations on different hard parts of Stizostedion vitreum showed that otoliths and pectoral fin rays had the highest rating, while 
pelvic fin rays had the lowest [25]. The otoliths generally provide the most accurate age, particularly in old fish [11], since otolith is the first calcified tissue formed during embryo development of fish [18] and it forms fine increments.

In a special case such as in Pagrus pagrus scales reading was more accurate than otoliths in annuli formation [26]. The precisions of each hard structure were discussed by Campana [3] (fig. 1).

\section{Accuracy and precision in otolith analysis}

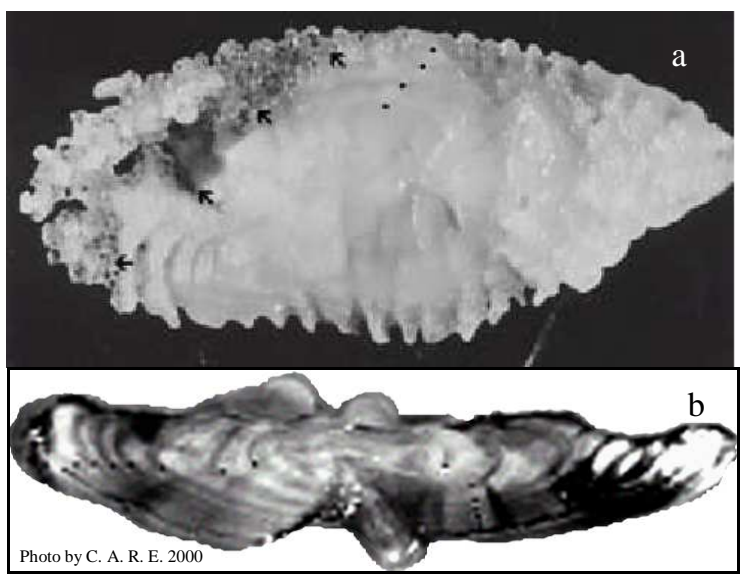

Fig. 2. Crystallized S. flavidus otolith

a) Distal surface showing partial crystallization (arrows). Annuli (dots) are difficult to distinguish

b) Burnt section of the otolith in a). Note that although crystallization has affected the dorsal tip

$(D)$ of the section, it does not interfere with the

ability to identify annuli (dots) and estimate age

In the otolith analysis methods, there were a lot of biases among readers [27] and among the methods of analysis [28, 29]. The equipment, magnification used, preparation and reader's experience all influenced accuracy and precision, in which polishing and reader's experience have the strongest effect [30].

Agreements between readers decreased with the increase of fish age. Also, age distribution varied greatly among species, and among samples of same species [31]; and variation between readers increased when the size and the age of fish increased [27].

The methods also create bias. The comparison between two methods of age determination for starry flounder, Campana [29] showed that the break and burn methods can reveal more annuli than whole otolith reading, and 'broken and burnt' otoliths showed an underestimation of age in older fish, relative to the results obtained from crosssection readings [28].

One disadvantage of the break and burn method is the reading variability caused by different angles of the light to the broken surface [28]. About 5-10\% of otoliths are crystallized, with abnormal shapes or unclear rings for analysis. These should be rejected, however, the other otolith of the pair can be quite acceptable [15], but C. A. R. E. [32] suggested that for those crystalline otoliths, a burnt section is often feasible (fig. 2).

\section{METHODS OF AGE VALIDATION}

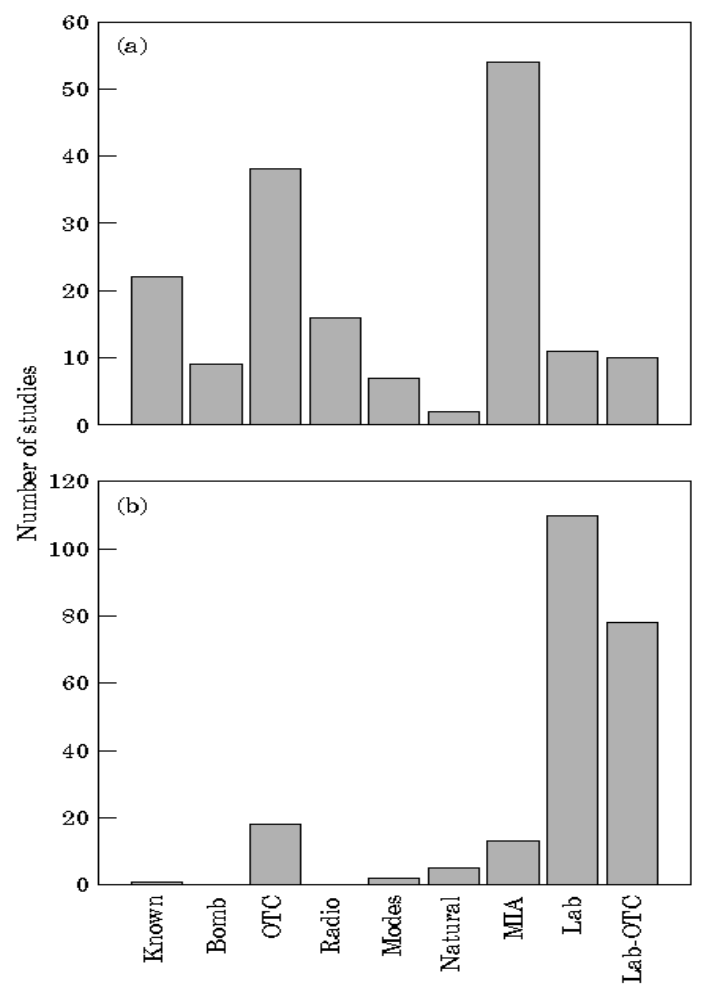

Fig. 3. Summary of papers reporting age validation after 1983, categorized by age validation method: (a) annual ages $(\mathrm{n}=205)$; (b) daily ages $(\mathrm{n}=162)$

Known: known age; Bomb: bomb radiocarbon; OTC: mark-recapture of chemically tagged wild 
fish; Radio: radiochemical dating; Modes: progression of length modes sampled for ages; Natural: natural, date-specific markers; MIA: marginal increment analysis; Lab: captive rearing from hatch; Lab-OTC: captive rearing after chemical marking [3]

Validation is a process that proves the accuracy and precision of a fish age determination method. Age determination techniques must be validated for all age classes in the population and for each time they are applied to a new species or sometimes to different population or stock [6]. This is because otolith formation is different among species, development stages and is affected by various endogenous and exogenous factors (see otolith formation).

Since the mid 1980's, more and more laboratories have become to understand the importance of validation and they have taken steps to assess the accuracy of their methodologies [32].

There are many different methods to validate otolith techniques for age determination, which depend on species and the study conditions. The utilization of each method was summarized by Campana [3] (fig. 3).

\section{Rearing fish}

The fish are hatched and cultured in the ponds or tanks. The hatched dates and the age of fish are known. The otoliths of known age fish are then used to compare with the otolith of the fish in nature. However, we have to consider that the conditions in captivity do not resemble in nature. This is an easy and cheap method to carry out with different development stages of fish life and check the formation and development of the fish otolith. However, we should consider the condition in captivity is different from natural condition.

\section{Mark and release}

\section{Mark and release known age fish}

The basis of this method is to mark the known age fish and release them to nature. The fish are then recaptured and the number of increments can be compared with the number of days in liberty. This technique is usually used for young fish from the hatcheries; and during most of the life time the fish are in nature [33]. This is the most exact age validation method because the age of the recaptured fish is known without error [3]. There are several methods of marking the fish for age validation.

Chemical marking: Chemicals used are oxytetracycline (OTC), alizarin, strontium or calcein. These chemicals deposited in the hard structures of the fish such as otolith, scale, bone, spine, vertebrate [34]. The numbers of increments deposited after marking can then be compared to the number of days or years since marking. This is mostly used for the larvae and juveniles from the hatcheries. The fish is immersed in a solution of the chemical or getting it via food. The dosages of chemicals and the immersion time are dependent on species [35].

Thermal marking: This technique is similar to chemical marking method, by putting the fish in fluctuating temperature regimes, distinct and recognisable patterns will appear in the otolith [36]. When water temperature is varied in a well-defined cycle, the fish will deposit sharply contrasting levels of calcium carbonate and protein (otolin) [32].

\section{Mark and release the wild fish}

This is one of the best methods for validating the growth increments in a certain period. The commonly used chemicals are the same as those used for larvae and juveniles. The process is immersion, injection or feeding, but injection was mostly used with different dosages [37]. The marked fish are released then recaptured. The number of increments after the mark in otolith can be compared with the number of days in liberty.

Mark and release method is possible to conduct with large amount of fish and the marked fish will live in the natural conditions, so the impact of the ambient environment on the otolith formation is the same as that of wild fish. However, any marking method has more or less impact on fish health and survival. 


\section{Radiometric assessment}

This process measures the proportion of radioisotopes $\quad\left({ }^{210} \mathrm{~Pb} /{ }^{226} \mathrm{Ra}, \quad{ }^{228} \mathrm{Th} /{ }^{228} \mathrm{Ra}\right.$, ${ }^{210} \mathrm{Po} /{ }^{10} \mathrm{~Pb}$ ) in otolith for estimating the age. Radioisotopes (e.g. ${ }^{226} \mathrm{Ra}$ ) enter the fish and otolith through normal metabolic processes, and it will decay radioactive daughter products (e.g. ${ }^{210} \mathrm{~Pb}$ ) and both are retained within the acellular crystalline structures of the otolith. The decay speed is known, thus if the amounts of them are known, the time of decay is calculated, and thereby validating the age of fish. This technique was suitable for long-lived fish [3].

\section{Assays of bomb radiocarbon}

This method is based on the nuclear testing during the 1950's and 1960's. It is like a large scale of chemical marking. Measurement of the amount of the ${ }^{14} \mathrm{C}$ in the core of the otolith allows determinating the age of the fish. The accuracy of this technique was $\pm 1-3$ years [3]; and used for long-lived fish, which were born between 1955 and 1985 [38, 39]. However, a recent study proved that this technique can also be used on short-lived fish [40]. Bomb radiocarbon is more accuracy than lengthweight method [41]. However, radioactive method is expensive and requires equipment.

\section{Counting daily increments between annuli}

This method is counting the daily increments between the annual hyaline rings. This method was used on a pelagic species in South African waters whose life is affected by two different environments (the warm Agulhas waters and the cold Benguela current). Using this method, the hyaline zones of Engraulis capensis otolith were found to contain both false rings and annuli. Scanning electron microscope (SEM) can be used to count the daily increments in hyaline zones [42].

\section{Length-frequency modes}

This is based on the length of fish by collecting samples of length each month at least for a year, then the relative age and the mean length are calculated [4]. Casselman [1] claimed that this method is useful for young fish, and fish with the short spawning period; and also best for fast growing juveniles [32]. However, this method has been proved to be less accurate than hard part analysis method and particular otolith analysis.

\section{Validating the first growth increment}

Identifying the first increment (daily or yearly) is very important and obligatory, because if the first increment is wrongly identified, the error will occur constantly.

Identification and validation of first growth increment can be conducted by using any method above but the best-suited way is releasing fish of known age or chemicalmarking young-of-year (YOY) [33]. Daily increment technique can be applied for species with clear microstructure increments to identification of the first annuli.

Acknowledgements: I would like to give many thanks to my teachers: Assoc. Prof. Vibeke Simonsen, Assoc. Prof. Peter Groenkjaer, Assoc. Prof. Tomas Cedhagen, Dr. Grete Dinesen, Dr. Jens Tang Christensen and Dr. Lars Chr. Lund-Hansen. I greatly appreciate all the people in the Marine Ecology Department and librarians at Aarhus Statsbiblioteket for their helps.

\section{REFERENCES}

1. Casselman, J. M., 1987. Determination of age and growth. The biology of fish growth. Academic Press. Great Britain. P. 209-242

2. Campana, S. E. and Neilson, J. D., 1985. Microstructure of fish otoliths. Canadian Journal of Fisheries and Aquatic Sciences, 42(5): 1014-1032.

3. Campana, S. E. (2001). Accuracy, precision and quality control in age determination, including a review of the use and abuse of age validation methods. Journal of fish biology, 59(2): 197-242.

4. King, M., 2013. Fisheries biology, assessment and management. Fishing new book. Blackwell Science Ltd. 341, p. 2001.

5. Casselman, J. M., 1983. Age and growth assessment of fish from their calcified structures-techniques and tools. NOAA Technical Report NMFS, 8: 1-17. 
6. Beamish, R. J., 1987. Current trends in age determination methodology. Age and growth of fish, 15-42.

7. Beamish, R. and McFarlane, G. A., 1983. The forgotten requirement for age validation in fisheries biology. Transactions of the American Fisheries Society, 112(6): 735-743.

8. Do, H. H., Grønkjar, P. and Simonsen, V., 2006. Otolith morphology, microstructure and ageing in the hedgehog seahorse, Hippocampus spinosissimus (Weber, 1913). Journal of Applied Ichthyology, 22(2): 153-159.

9. Đỗ Hũu Hoàng, 2003. Đá tai và một số phương pháp xác định tuổi cá (Tổng quan). Tuyển tập Nghiên cứu biển - Tập XIII, 225 235.

10. Hà Phước Hùng, Hồ Kim Lợi, 2013. Nghiên cứu hình thái đá tai của họ cá chép (Cyprinidae) phân bố ở An Giang và Cần Thơ. Tạp chí Khoa học Trường Đại học Cần Thơ, 26: 50-54.

11. Campana, S.E., 2004. Photographic Atlas of Fish Otoliths of the Northwest Atlantic Ocean. NRC Research Press, Ottawa, Ontario. $284 \mathrm{p}$.

12. Härkönen, T., 1986. Guide to the otoliths of the bony fishes of the northeast Atlantic. Danbiu ApS. Biological Consultants, Hellerup, Denmark. Printed in Sweden. 256 p.

13. Pannella, G., 1980. Growth patterns in fish sagittae. In: Rhoads, D.C. \& R.A. Lutz (eds). Skeletal Growth of Aquatic Organisms. Biological Records of Environmental Change. Plenum Press, New York. Pp: 519-560.

14. FAO, 1981. Methods of Collecting and Analysing Size and Age Data for Fish Stock Assessment. FAO fisheries circular; no. 736. Food and Agriculture Organization of The United Nations, Rome, Oct. 1981. $104 \mathrm{p}$.

15. Gjosaeter, J., Dayaratne, P., \& Bergstad, O. A., 1984. Ageing tropical fish by growth rings in the otoliths.
16. Murayama, E., Takagi, Y., Ohira, T., Davis, J. G., Greene, M. I. and Nagasawa, H., 2002. Fish otolith contains a unique structural protein, otolin-1. European Journal of Biochemistry, 269(2): 688-696.

17. Fowler, A. J., Campana, S. E. and Thrrold, S. R., 1995. Experimental assessment of the effect of the temperature and salinity on elemental composition of otoliths using laser ablation ICPMS. Canadian Special Publication of Fisheries and Aquatic Sciences, 52(7): 1431-1441.

18. Radtke, R. L. and Dean, J. M., 1982. Increment formation in the otoliths of embryos, larvae, and juveniles of the mummichog, fundulus-heteroclitus. Fishery Bulletin, 80(2): 201-215.

19. Campana, S.E. and Fowler, M., 2012. Age Determination without Tears: Statistical Estimation of Silver Hake (Merluccius bilinearis) Age Composition on the Basis of Otolith Weight and Fish Length. DFO Can. Sci. Advis. Sec. Res. Doc. 2012/079. $\mathrm{ii}+19 \mathrm{p}$.

20. Bilton, H. T., 1974. Effects of starvation and feeding on circulus formation on scales of young sockeye salmon of four racial origins, and of one race of young kokanee, coho and chinook salmon. In: Bagenal T. B. (ed). Ageing of Fish. The Proceedings of an International Symposium on The Ageing of Fish. Unwin Brothers Ltd. The Gresham Press, England. Pp. 40-70.

21. Campana, S. E., 1984. Lunar cycles of otolith growth in the juvenile starry flounder Platichthys stellatus. Marine biology, 80(3): 239-246.

22. Pannella, G., 1971. Fish otoliths: daily growth layers and periodical patterns. Science, 173(4002): 1124-1127.

23. Oxenford, H. A., Hunte, W., Deane, R., and Campana, S. E., 1994. Otolith age validation and growth-rate variation in flyingfish (Hirundichthys affinis) from the eastern Caribbean. Marine Biology, 118(4): 585-592.

24. Lowerrebarbieri, S., Chittenden, M. and Jones, C. M., 1994. A comparison of a 
validated otolith method to age weakfish, Cynoscion regalis, with the traditional scale method. Fishery Bulletin. 92, 555-568.

25. Belanger, S. E., and Hogler, S. R., 1982. Comparison of Five Ageing Methodologies Applied to Walleye (Stizostedion Vitreum) in Burt Lake, Michigan. Journal of Great Lakes Research, 8(4): 666-671.

26. Machias, A., Tsimenides, N., Kokokiris, L., and Divanach, P., 1998. Ring formation on otoliths and scales of Pagrus pagrus: a comparative study. Journal of fish biology, 52(2): 350-361.

27. Eklund, J., Parmanne, R., \& Aneer, G., 2000. Between-reader variation in herring otolith ages and effects on estimated population parameters. Fisheries Research, 46(1): 147-154.

28. Stransky, C., Gudmundsdóttir, S., Sigurdsson, T., Lemvig, S., Nedreaas, K., \& Saborido-Rey, F., 2003. Age readings of Sebastes marinus and S. mentella otoliths: bias and precision between readers.

29. Campana, S. E., 1984. Comparison of Age Determination methods for Starry Flounder. Transactions of American Fisheries Society. 113(3): 365-369.

30. Campana, S. E., and Moksness, E., 1991. Accuracy and precision of age and hatch date estimates from otolith microstructure examination. ICES Journal of Marine Science: Journal du Conseil, 48(3): 303316.

31. Kimura, D. K., \& Lyons, J. J., 1991. Between-reader bias and variability in the age-determination process. Fishery Bulletin, 89(1): 53-60.

32. C. A. R. E., 2000. Manual on Generalized Age Determination Procedures For Groundfish. Prepared by: C.A.R.E. (Committee of Age Reading Experts) Pacific Coast Groundfish Ageing Technicians. Under the Sponsorship of Pacific States Marine Fisheries Commission. For: The Technical Subcommittee of The Canada/U.S. Groundfish Committee. May, 2000.
33. Dwyer, K. S., Walsh, S. J. and Campana, S. E., 2003. Age determination, validation and growth of Grand Bank yellowtail flounder (Limanda ferruginea). ICES Journal of Marine Science: Journal du Conseil, 60(5): 1123-1138.

34. Campana, S. E., 1999. Chemistry and composition of fish otoliths: Pathways, mechanisms and applications. Marine Ecology Progress Series. 188, 263-297.

35. Brooks, R.C., Heidinger, R.C. and Kohler, C.C., 1994. Mass-marking otoliths of larval and juvenile walleyes by immersion in oxytetracycline, calcein, or calcein blue. North American Journal of Fisheries Management, 14(1): 143-150.

36. Letcher, B. H. and Terrick, T. D., 1998. Thermal marking of Atlantic salmon otoliths. North American Journal of Fisheries Management, 18(2): 406-410.

37. Hining, K. J., West, J. L., Kulp, M. A. and Neubauer, A. D., 2000. Validation of Scales and Otoliths for Estimating Age of Rainbow Trout from Southern Appalachian Streams. North American Journal of Fisheries Management, 20(4): 978-985.

38. Armsworthy, S. L., and Campana, S. E., 2010. Age determination, bombradiocarbon validation and growth of Atlantic halibut (Hippoglossus hippoglossus) from the Northwest Atlantic. Environmental biology of fishes, 89(3-4): 279-295.

39. Morin, R., LeBlanc, S. G., and Campana, S. E., 2013. Bomb Radiocarbon Validates Age and Long-Term Growth Declines in American Plaice in the Southern Gulf of St. Lawrence. Transactions of the American Fisheries Society, 142(2): 458-470.

40. Melvin, G. D., and Campana, S. E., 2010. High resolution bomb dating for testing the accuracy of age interpretations for a shortlived pelagic fish, the Atlantic herring. Environmental biology of fishes, 89(3-4): 297-311.

41. Neilson, J. D., and Campana, S. E., 2008. A validated description of age and growth of western Atlantic bluefin tuna (Thunnus 
Do Huu Hoang

thynnus). Canadian Journal of Fisheries and Aquatic Sciences, 65(8): 1523-1527.

42. Waldron, M. E., 1994. Validation of annuli of the South African anchovy, Engraulis capensis, using daily otolith growth increments. ICES Journal of Marine Science: Journal du Conseil, 51(2): 233234.

\section{TÍNH CHÍNH XÁC CỦA PHƯƠNG PHÁP PHÂN TÍCH ĐÁ TAI VÀ PHƯONG PHÁP GIÁM ĐỊNH}

\section{Đỗ Hữu Hoàng}

Viện Hải dương học-Viện Hàn lâm Khoa học và Công nghệ Việt Nam

TÓM TÁT: Tuổi và sinh truởng là dũ liệu vô cùng quan trong trong quản lý nghề cá. Cấu trúc tuổi và sinh truởng của quần đàn giúp cho việc quản lý và khai thác một cách hiệu quả và bền vũng. Mặc dù đá tai được sử dụng rất phổ biến và là phuoong pháp khá chính xác để đánh giá tuổi cá. Tuy nhiên, việc định tuổi này cần thiết phải giám định lại đối với tù̀ng loài, tù̀ng phuoong pháp nghiên cứu và tùng vùng địa lý nhất định, bởi vì việc hình thành đá tai của cá chịu sụ ảnh huởng của các nhân tố vô sinh, hữu sinh và chính bản thân của tùng loài. Nội dung bài viết này trình bày chức năng của đá tai và việc hình thành đá tai và nhũng nhân tố ảnh huoởng đến việc hình thành đá tai của cá. Đồng thời giới thiệu một số phuơng pháp nhằm khăng định việc đọc tuổi cá là đúng, bao gồm: nuôi nhốt, đánh dấu - thả và bắt lại, nghiên cưu đồng vị phóng xạ, đếm số vòng giữa hai vòng năm, tính tần số chiều dài và xác định vòng tuổi đầu tiên.

Tù khoá: Đá tai, tuổi cá, sinh trương, kiểm nghiệm. 